ISSN : 1412-7601

Volume 3, No.2 September 2017

http://www.ekonobis.unram.ac.id

EKONOBIS

\title{
Analisis Perkembangan Asset, DPK, Kredit dan Kapital Bank Perkreditan Rakyat (BPR) SeNusa Tenggara Barat
}

\author{
Yusuf Hasbullah. \\ Universitas Mataram
}

\begin{tabular}{l}
\hline A R T ICLE I N F O \\
\hline Keywords: \\
Asset, DPK, Credit, \\
Capital, Rural Bank (BPR), \\
West Nusa Tenggara
\end{tabular}

Kata Kunci :

Analisis Perkembangan

Asset, DPK,

Kredit,Kapital,Bank

Perkreditan Rakyat

(BPR), Nusa Tenggara

Barat
Received : 20 Juni 2017; Accepted: 18 Juli 2017; Published: September 2017

ABSTRACT : This research entitled Analysis of Asset Development, DPK, Credit and Rural Bank Credit (BPR) in West Nusa Tenggara. The purpose of this study is to: To know the development of Rural Bank (BPR) in terms of Asset, Third Party Fund (DPK), Credit and Capital in West Nusa Tenggara. According to the level of explanation this type of research includes descriptive research that will describe how the information about society and government on the Development of Rural Banks (BPR) in terms of Asset, Third Party Fund (DPK), Credit and Capital in West Nusa Tenggara. The method used is census, where all the existing BPR in NTB will be verified data that has been updated according to the needs of research and has been published. While the data to be used is secondary data. From the data analysis, 32 (thirty two) Rural Banks (BPR) in West Nusa Tenggara Province found that there are 5 (five) BPRs that have the most Assets from 32 BPRs in West Nusa Tenggara such as: PT. BPR Prima Nadi with Asset 118,626 billion, PT. BPRS Dinar Ashri with 91.957 billion Assets, PD.BPR NTB Sumbawa with Assets 87,096 billion, PD.BPR.Lombok Tengah with 85.451 billion Assets and PT.BPR Samawa Kencana with assets of 81,850 billion. If there are seen in terms of DPK, there are 5 (five) BPRs that can generate funds from 32 BPRs in West Nusa Tenggara such as: PT.BPR.Prima Nadi amounting to 101,191 million, PT.BPR Samawaq Kencana totaling 72.864 million, PT. BPRS Dinar Ashri of 53.517 million, PD.BPR Central Lombok of 50.347 million and PD.BPR.NTB Sumbawa of 47.835 million. In terms of credit, there are 5 (five) BPRs that have distributed the most credit from 32 BPRs in West Nusa Tenggara such as: PT.BPR Prima Nadi of 84,093 million, PD.BPR NTB Central Lombok 80.363 million, PD.BPR NTB Sumbawa amounted to 75,267 million, West Lombok BPR PD of 59.865 million and PT BPR Samawa Kencana totaling 58.653 million.

ABSTRAK : Penelitian ini berjudul Analisis Perkembangan Asset, DPK, Kreditdan Kapital Bank Perkreditan Rakyat (BPR) se Nusa Tenggara Barat. Adapun Tujuan penelitian ini adalah untuk: Untuk mengetahui Perkembangan Bank Perkreditan Rakyat (BPR) ditinjau dari segi Asset, Dana Pihak Ketiga (DPK), Kredit dan Capital di Nusa tenggara Barat. Menurut tingkat eksplanasinya jenis penelitian ini termasuk penelitian deskriptif yang akan mendeskripsikan bagaimana gambaran kepada masyarakat dan pemerintah daerah tentang Perkembangan Bank Perkreditan Rakyat (BPR) ditinjau dari segi Asset, Dana Pihak Ketiga (DPK), Kredit dan Capital di Nusa tenggara Barat. Adapun metode yang digunakan adalah metode sensus, dimana seluruh BPR yang ada di NTB ini akan dilakukan verifikasi data-datanya yang sudah di update sesuai kebutuhan penelitian dan sudah dipublikasi. Sedangkan data yang akan digunakan adalah data skunder. Dari hasil analisis data sebanyak 32 (tiga puluh dua) Bank perkreditan Rakyat (BPR) yang ada di Provinsi Nusa Tenggara Barat ditemukan bahwa ada 5 (lima) BPR yang mempunyai Asset terbanyak dari 32 BPR yang ada di Nusa tenggara Barat seperti : PT. BPR Prima Nadi dengan Asset 118.626 milyar, PT. BPRS Dinar Ashri dengan Asset 91.957 milyar, PD.BPR NTB Sumbawa dengan Asset 87.096 milyar, PD.BPR.Lombok Tengah dengan Asset 85.451 milyar dan PT.BPR Samawa Kencana dengan asset 81.850 milyar. Sedangkan jika dilihat dari segi DPK ada 5 (lima) BPR yang mampu menyerap dana pihak ketiga dari 32 BPR yang ada di Nusa Tenggara Barat seperti : PT.BPR.Prima Nadi sebesar 101.191 juta, PT.BPR Samawaq Kencana sebesar 72.864 juta, PT. BPRS Dinar Ashri sebesar 53.517 juta, PD.BPR Lombok Tengah sebesar 50.347 juta dan PD.BPR.NTB Sumbawa sebesar 47.835 juta. Sedangkan ditinjau dari segi Kredit ada 5 (lima) BPR yang telah menyalurkan kredit terbanyak dari 32 BPR yang ada di Nusa Tenggara Barat seperti : PT.BPR Prima Nadi sebesar 84.093 juta, PD.BPR NTB Lombok Tengah sebesar 80.363 juta, PD.BPR NTB Sumbawa sebesar 75.267 juta, PD BPR NTB Lombok Barat sebesar 59.865 juta dan PT BPR Samawa Kencana sebesar 58.653 juta.

Corresponding Author:

Alamat: Program Studi Ekonomi Pembangunan, Fakultas Ekonomi dan Bisnis, Universitas Mataram, Jln. Majapahit No. 62 Mataram.

e-mail: yusufhasfeb@unram.ac.id 


\section{PENDAHULUAN}

\section{Latar Belakang}

Lembaga keuangan Perbankan
merupakan salah satu sarana pembangunan, dimana perbankan diharapkan mampu mengembangkan dan memajukan perekonomian di Indonesia. Khususnya dalam meningkatkan pemerataan kesejahteraan rakyat banyak, dalam hal ini bukan kesejahteraan segolongan orang atau perorangan saja melainkan kesejahteraan seluruh rakyat Indonesia tanpa terkecuali. Dalam hal ini menandakan bahwa bank sangatlah penting dalam pembangunan nasional karena fungsi bank dalam Pasal 1 angka 2 UU perbankan mendifinisikan fungsi bank adalah badan usaha yang menghimpun dana dari masyarakat dalam bentuk simpanan dan menyalurkannya kepada masyarakat dalam bentuk kredit dan atau bentuk-bentuk lainnya dalam rangka meningkatkan taraf hidup rakyat banyak.

Lembaga keuangan Perbankan memberikan kesempatan kepada masyarakat untuk berpartisipasi dalam pembangunan dengan mengadakan pengumpulan dana melalui usaha-usaha yang dijalankan perbankan, seperti tabungan, deposito, maupun kredit. Adanya tabungan, deposito, maupun kredit menimbulkan terjadinya perputaran uang di masyarakat sehingga dapat dipergunakan untuk pembangunan. Untuk mencapai maksud dan tujuan tersebut Perusahaan Daerah Bank Perkreditan Rakyat menyelenggarakan usaha-usaha antara lain:

1. Menghimpun dana dari masyarakat dalam bentuk tabungan dan deposito berjangka,

2. Memberikan kredit dan melakukan pembinaan, khususnya terhadap pengusaha golongan ekonomi lemah,

3. Melakukan kerjasama antar Bank Perkreditan Rakyat dan dengan Lembaga Perbankan atau Lembaga Keuangan lainnya,

4. Menjalankan usaha-usaha perbankan lain, sepanjang tidak bertentangan dengan Peraturan Perundang-undangan yang berlaku.
Usaha-usaha di atas, terutama dimaksudkan untuk mendukung pelaksanaan pembangunan nasional di segala bidang. Usaha perkreditan dalam dunia perbankan merupakan kegiatan usaha yang paling utama, karena pendapatan terbesar dalam usaha perbankan berasal dari pendapatan kegiatan usaha kredit. Ruang lingkup kredit sebagai kegiatan perbankan tidak semata-mata hanya menyangkut kegiatan peminjaman kepada nasabah, melainkan sangat komplek, menyangkut keterkaitan unsur-unsur yang cukup banyak diantaranya meliputi; alokasi dana, perjanjian kredit, organisasi dan managemen perkreditan, kredit-kredit bermasalah dan penyelesaian kredit-kredit bermasalah tersebut.

Kredit merupakan salah satu program bank mewujudkan pembangunan nasional dibidang ekonomi, yang diharapkan dapat meningkatkan kesejahteraan rakyat banyak. Kredit yang diberikan oleh bank kepada rakyat mengandung resiko sehingga dalam pemberian kredit harus memperhatikan asas-asas perkreditan yang sehat berdasarkan prinsip kehatihatian. Untuk itu sebelum memberikan kredit bank harus melakukan penilaian yang seksama terhadap berbagai aspek khususnya dalam penilaian terhadap jaminan.

Pemerintah dalam memberikan kredit lebih mengutamakan pengusaha atau perusahaan kecil golongan ekonomi lemah. Pengusaha atau perusahaan kecil golongan ekonomi lemah adalah pengusaha atau perusahaan, dengan kondisi sebagai berikut:

1. Sekurang-kurangnya $50 \%$ dari modal disetor dimiliki oleh orang Indonesia asli, dan sebagian besar dari tiap-tiap pengurus (dewan komisaris dan/atau direksi) adalah orang Indonesia asli atau sekurang-kurangnya $75 \%$ dari modal usaha dimiliki oleh orang Indonesia asli. Yang termasuk orang Indonesia asli ialah mereka yang sudah membaur sebagai orang Indonesia asli. 
2. Besar modal/kekayaan bersih usaha adalah penerima KIK dan KMKP yang mempunyai jumlah harta (total assets) tidak melebihi Rp 300 juta yang berlaku untuk semua sektor ekonomi, tidak termasuk nilai tanah dan rumah yang ditempati. Sedangkan menurut Keppres Nomor: 29 tahun 1984, penerima KIK dan KMKP sampai dengan Rp 75 juta, mempunyai jumlah harta (total assets) tidak melebihi Rp 600 juta.

Permasalahannya, prosedur pelaksanaan pemberian kredit untuk pengusaha atau perusahaan kecil golongan ekonomi lemah tidak mudah. Ada persyaratanpersyaratan yang harus dipenuhi oleh kreditur dan petugas bank terkesan memilih-milih nasabah yang akan diberi kredit. Di sisi lain tindakan petugas bank tersebut dilakukan karena sebagian besar kreditur dalam menggunakan uangnya sering menyimpang dari alasan saat pengambilan kredit, yaitu kreditur menggunakan uang untuk kepentingan pribadi bukan untuk kepentingan usahanya.

Pemerintah Provinsi Nusa Tenggara Barat dalam mendukung prekonomian masyarakatnya memiliki lembaga perbankan hampir di semua Kabupaten/Kota seperti Bank Perkreditan Rakyat (BPR). Adapun kepemilikan sahamnya dibagi dua sesuai dengan Peraturan Daerah No : 8 Tahun 2009, dimana saham pemerintah Provinsi sebesar $60 \%$ dan pemerintah Kabupaten/kota sebesar $40 \%$ yang disetorkan secara bertahap. Salah satu Bank Perkreditan Rakyat yang ada di Kabupaten lombok Barat bernama BPR NTB Lombok Barat. Dilihat dari sejarahnya BPR yang ada di Nusa Tenggara Barat ini berasal dari Lembaga Kredit Pedesaan (LKP) yang kemudian dikonsolidasi pada tahun 2010 dan terjadi perubahan nama dari LKP menjadi Bank Perkreditan Rakyat (BPR). Dalam perjalanannya setelah konsolidasi tahun 2010 perkembangan BPR khusunya BPR NTB Lombok Barat mengalami perkembangan yang cukup significan, baik dari segi asset, kredit, nasabah, baki debet dan keuntungan.
Kendatipun dalam perjalanannya terjadi berbagai persoalan, namun secara ekonomi telah banyak memberikan sumbangan terhadap perkembangan usaha kecil dan mikro yang ada di pedesaan. Karena sesuai dengan filosofisnya keberadaan BPR dihajatkan untuk dapat melayani usaha kecil dan mikro yang tidak dapat didanai oleh Bankbank konvensional.

\section{Perumusan Masalah}

Berangkat dari latar belakang diatas maka dalam penelitian ini dapat dirumuskan permasalahannya sebagai berikut : Bagaimana Perkembangan Bank Perkreditan Rakyat (BPR) ditinjau dari segi Asset, Dana Pihak Ketiga (DPK), Kredit dan Capital di Nusa Tenggara Barat.

\section{Tujuan Penelitian}

Adapun tujuan dari penelitian ini adalah : Untuk mengetahui Perkembangan Bank Perkreditan Rakyat (BPR) ditinjau dari segi Asset, Dana Pihak Ketiga (DPK), Kredit dan Capital di Nusa tenggara Barat.

\section{LANDASAN TEORI}

\section{Pengertian Bank}

Pengertian bank menurut undang-undang perbankan UU No.10 tahun 1998 Pasal 1 adalah badan usaha yang menghimpun dana dari masyarakat dalam bentuk simpanan dan menyalurkan kepada masyarakat dalam bentuk kredit dan / atau bentuk-bentuk lainya dalam rangka meningkatkan taraf hidup rakyat banyak.

Bank umum adalah bank yang melaksanakan kegiatan usaha secara konvensional dan / atau berdasarkan Prinsip Syariah yang dalam kegiatannya memberikan jasa dalam lalu lintas pembayaran. Bank Perkreditan Rakyat (BPR) adalah bank yang melaksanakan kegiatan usaha secara konvensional atau berdasarkan Prinsip Syariah yang dalam kegiatannya tidak memberikan jasa dalam lalu lintas pembayaran.

Mengenai asas perbankan menurut pasal 2 UU No.10 tahun 1998 menyebutkan Perbankan Indonesia dalam melakukan usahanya berasaskan demokrasi ekonomi 
dengan menggunakan prinsip kehatihatian. Yang dimaksud dengan demokrasi ekonomi adalah demokrasi ekonomi yang berdasarkan pancasila dan UndangUndang Dasar 1945.

Kemudian fungsi utama perbankan Indonesia dalam pasal 3 UU No.10 tahun 1998 menyebutkan, bahwa perbankan Indonesia mempunyai fungsi utama yaitu sebagai penghimpun dan penyalur dana masyarakat. Sejalan dengan fungsi utama dimaksud, tujuan perbankan Indonesia sebagaimana yang tercantum dalam pasal 4 UU No.10 tahun 1998 adalah menunjang pelaksanaan pembangunan nasional dalam rangka meningkatkan pemerataan, pertumbuhan ekonomi, dan stabilitas nasional ke arah peningkatan kesejahteraan rakyat banyak.

\section{Jenis-jenis Bank}

Praktik perbankan di Indonesia saat ini yang diatur dalam Undang-Undang perbankan memiliki beberapa jenis Bank. Dalam buku karangan Kasmir berjudul Manajemen perbankan menjelaskan mengenai jenis-jenis perbankan.

Perbedaan jenis perbankan dapat dilihat dari segi fungsi, kepemilikan dan dari segi menentukan harga. Dari segi fungsi perbedaan yang terjadi terletak pada luasnya kegiatan atau jumlah produk yang dapat ditawarkan maupun jangkauan wilayah operasinya. Kemudian kepemilikan perusahaan dilihat dari segi pemilikan saham yang ada serta akte pendiriannya. Sedangkan dari menentukan harga yaitu Bank Konvensional berdasarkan bunga dan Bank Syariah berdasarkan bagi hasil. Untuk lebih jelasnya jenis perbankan dewasa ini menurut Kasmir ditinjau dari berbagai segi antara lain :

\section{a. Dilihat dari segi fungsinya}

Dilihat dari segi fungsinya bank menurut Undang-Undang Perbankan nomor 7 tahun 1992 dan ditegaskan lagi dengan dikeluarkannya UndangUndang RI. Nomor 10 tahun 1998 maka jenis perbankan terdiri dari dua jenis bank yaitu:

1) Bank Umum

2) Bank Perkreditan Rakyat ( BPR )

Bank Perkreditan Rakyat ( BPR ) menurut Pasal 19 ayat (1) menyatakan bahwa pembukaan Kantor Cabang Bank Perkreditan Rakyat hanya dapat dilakukan dengan ijin Pimpinan Bank Indonesia.

\section{b. Dilihat dari Segi Kepemilikan}

Jenis bank selanjutnya dapat dilihat dari segi kepemilikan. Jenis Bank dilihat dari segi kepemilikan maksudnya adalah siapa saja yang memiliki Bank tersebut. Kepemilikan ini dapat dilihat dari akte pendirian dan penguasaan saham yang dimiliki Bank yang bersangkutan.

Jenis Bank dilihat dari segi kepemilikan adalah sebagai berikut:

1) Bank milik Pemerintah

Dimana baik akte pendirian maupun modalnya dimiliki oleh pemerintah, sehingga seluruh keuntungan Bank ini dimiliki oleh pemerintah pula. Contoh: Bank Negara Indonesia 46 (BNI), Bank Rakyat Indonesia ( BRI ), Bank Tabungan Negara (BTN), dan Bank Mandiri.

2) Bank milik swasta nasional

Merupakan Bank yang seluruhnya atau sebagian besarnya dimiliki oleh swasta nasional serta akte pendiriannya pun didirikan oleh swasta, begitu pula pembagian keuntungan diambil oleh swasta pula. Contoh Bank milik swasta nasional antara lain: Bank Bumi Putra, Bank Bukopin, Bank Central Asia, Bank Danamon, Bank Lippo, dan Bank swasta lainnya.

3) Bank milik asing

Bank milik asing merupakan cabang dari Bank yang ada diluar negeri, baik Bank swasta asing maupun pemerintah asing suatu negara. Contoh Bank milik asing antara lain: ABN AMRO Bank, America Expres Bank, dan Bank Asing lainnya

4) Bank milik campuran

Bank milik campuran merupakan Bank yang kepemilikan sahamnya dimiliki oleh pihak asing dan pihak swasta nasional. Dimana kepemilikan sahamnya secara mayoritas dipegang oleh warga negara Indonesia. Contoh Bank campuran antara lain: Bank Finconesia dan Bank Merincorp.

\section{c. Dilihat dari segi status}

Pembagian jenis bank dari segi status merupakan pembagian berdasarkan 
kedudukan atau status Bank tersebut. Kedudukan atau status ini menunjukkan ukuran kemampuan Bank dalam melayani masyarakat baik dari segi jumlah produk, modal maupun kualitas pelayanannya. Oleh karena itu untuk memperoleh status tersebut diperlukan penilaian-penilaian dengan kriteria tertentu. Jenis Bank bila dilihat dari segi status biasanya khusus untuk Bank umum.

Dalam praktiknya jenis Bank dilihat dari status dibagi kedalam dua macam yaitu :

\section{1) Bank devisa}

Bank yang berstatus devisa atau Bank devisa merupakan Bank yang dapat melaksanakan transaksi keluar negeri atau yang berhubungan dengan mata uang asing secara keseluruhan.

2) Bank non devisa

Merupakan kebalikan daripada Bank devisa, dimana transaksi yang dilakukan masih dalam batas-batas suatu negara.

d. Dilihat dari Segi Cara Menentukan Harga

Ditinjau dari segi menentukan harga dapat pula diartikan sebagai cara penentuan keuntungan yang akan diperoleh. Jenis Bank jika dilihat dari segi atau caranya dalam menentukan harga baik harga jual maupun harga terbagi dalam dua kelompok, yaitu:

1) Menetapkan bunga sebagai harga jual, baik untuk produk simpanan seperti giro, tabungan maupun deposito.

2) Untuk jasa-jasa Bank lainnya pihak perbankan konvensional

menggunakan atau menerapkan berbagai biaya-biaya dalam nominal atau persentase tertentu seperti biaya provisi, sewa, iuran dan biaya-biaya lainya.

\subsection{Bank Perkreditan Rakyat}

1. Pengertian Bank Perkreditan Rakyat Pengertian Bank Perkreditan Rakyat (BPR) menurut Pasal 1 ayat (4) Undang-undang nomor 10 tahun 1998 adalah: "Bank yang melaksanakan kegiatan usahanya secara konvensional atau berdasarkan Prinsip Syariah yang dalam kegiatannya tidak memberikan jasa dalam lalu lintas pembayaran.
Artinya di sini kegiatan BPR jauh lebih sempit jika dibandingkan dengan kegiatan Bank Umum. Kegiatan BPR hanya meliputi kegiatan penghimpunan dan penyaluran dana saja, bahkan dalam menghimpun dana BPR dilarang untuk menerima simpanan giro. Begitu pula dalam hal jangkauan wilayah operasi, BPR hanya dibatasi dalam wilayahwilayah tertentu saja. Selanjutnya pendirian BPR dengan modal awal yang relatif lebih kecil jika di banding dengan modal awal Bank Umum. Larangan lain bagi BPR adalah tidak ikut kliring serta transaksi valuta asing.

Dalam hal menjalankan kegiatan usahanya, maka sesuai dengan Pasal 13 UU Nomor 10 Tahun 1998 tentang Perbankan, BPR dapat melakukan hal-hal sebagai berikut :

1. Menghimpun dana dari masyarakat dalam bentuk simpanan berupa deposito berjangka, dan atau bentuk lainnya yang dipersamakan dengan itu,

2. Memberikan kredit;

3. 3.Menyediakan pembiayaan bagi nasabah berdasarkan prinsip syariah;

4. Menempatkan dananya dalam bentuk Sertifikat Bank Indonesia (SBI), deposito berjangka, sertifikat deposito, dan atau tabungan pada bank lain;

Selain kegiatan usaha yang diperbolehkan seperti halnya jenis usaha-usaha di atas, juga ditentukan ada beberapa larangan yang membatasi kegiatan usaha Bank Perkreditan Rakyat, larangan tersebut meliputi:

a. menerima simpanan giro dan ikut serta dalam lalu lintas pembayaran;

b. melakukan kegiatan usaha dalam valuta asing;

c. melakukan penyertaan modal;

d. melakukan kegiatan usaha perasuransian;

e. melakukan usaha lain di luar kegiatan usaha seperti di atas. 


\section{Perkembangan Bank Perkreditan Rakyat (BPR)}

Perkembangan Bank Perkreditan Rakyat dimaksudkan dalam beberapa aspek seperti :

1. Perkembangan Asset

2. Perkembangan Dana Pihak Ketiga (DPK)

3. Perkembangan Kredit dan

4. Perkembangan Permodalan.

Perkembangan Bank Perkreditran Rakyat disni diharapkan akan dapat memberikan gambara faktual kepada masyarakat terutama dalam hal menentukan pilihan Bank Perkreditan mana yang memopunyai tingkat usaha yang paling menguntungkan, sehingga dapat menentukan pilihan masyarakat dalam hal penempatan dananya secara produktif. Dari segi pemerintah daerah agar dapat melakukan pembinaan terhadap masingmasing bank Perkreditan Rakyat yang masih mempunyai perkembangan yang rendah atau kurang sehat dilihat dari berbagai aspek penilaian tingkat kesehatan perbankan.

\section{METODE PENELITIAN}

\section{Jenis Penelitian}

Penelitian ini termasuk penelitian deskriptif, yaitu suatu penelitian dengan menyajikan dan mendiskripsikan datadata seteliti mungkin tentang deskripsi perkembangan BPR se-NTB baik ditinjau dari perkembangan Asset, Dana Pihak Ketiga (DPK), Kredit dan Permodalan (Capital) selama tahun 2013. Dengan diketahuinya semua spek tersebut diatas, maka akan dapat diketahui tingkat perkembangan BPR se-NTB.

\section{Jenis dan Sumber Data}

Adapun jenis data yang akan digunakan dalam penelitian ini menggunakan :

Data skunder, dimana data dimaksud akan diperoleh secara langsung dan bersumber dari Bank Perkreditan Rakyat se-Nusa Tenggara Barat dan publikasi Bank Indonesia sebagai lembaga pembina yang sudah dipublikasikan yang meliputi data : perkembangan asset, perkembangan dana pihak ketiga (DPK), perkembangan kredit dan perkembangan modal.

\section{Teknik Pengumpulan data}

\section{a. Observasi}

Tindakan observasi ini dilakukan melalui pengamatan dan verifikasi data-data Bank Perkreditan Rakyat se Nusa Tenggara Barat yang sudah dipublikasikan baik berupa data, keterangan, fakta atau gejala lainnya pada obyek yang diteliti. Dalam observasi ini ditekankan pada datadata yang akan dianalisis sesuai permasalahan di atas.

\section{b. Studi Kepustakaan}

Untuk menunjang metode diatas dilakukan studi Pustaka yaitu yang dilakukan dengan cara mencari sumber-sumber bacaan, mempelajari refrensi yang langsung terkait dengan tema penelitian di atas.

\section{Teknik Analisis Data}

Untuk melakukan analisis terhadap perkembangan Bank Perkreditan Rakyat (BPR) akan dilakukan dengan menggunakan pendekatan Analisis Pertumbuhan.

Guna mendapatkan gambaran tentang pertumbuhan Perbankan selama lima tahun terakhir (2009-2013) akan dianalisis dengan formulasi Widodo dalam Muin (2003: 36) sebagai berikut :

$$
\Delta \mathrm{Xt}=\frac{\mathrm{Xit}-\mathrm{Xit}-1}{\mathrm{Xit}-1} \times 100 \%
$$

dimana:

$\Delta \mathrm{Xt}=$ Laju pertumbuhan Perbankan

$\Delta \mathrm{Xit}=$ Laju pertumbuhan tahun $\mathrm{X}$

$\Delta$ Xit-1= Laju pertumbuhan tahun $\mathrm{X}-1$

$\mathrm{t}=$ Tahun $\mathrm{X}$

$\mathrm{t}-1=$ Tahun Sebelumnya

Melalui analisis pertumbuhan di atas selanjutnya akan dilihat masing-masing komponen dengan menggunakan pendekatan di atas seperti : Assets, DPK, Kredit dan Capital.

\section{HASIL DAN PEMBAHASAN}

\section{Aktivitas Utama Perbankan}

Sebagaimana dimaklumi bahwa berdasarkan Undang-Undang Nomor : 7 
Tahun 1992 sebagaimana telah diubah dengan Undang - Undang Nomor : 10 Tahun 1998 tentang perbankan, bahwa tugas dan fungsi BPR adalah menghimpun dana masyarakat dan menyalurkan kembali dalam bentuk kredit dan tidak di perkenankan memberikan jasa dalam lalu lintas pembayaran, dengan demikian tugas dan aktivitas utama PD.BPR. NTB Lombok Barat hanya menghimpun dana dari masyarakat dan menyalurkan dana kepada masyarakat dalam bentuk kredit. Jenis produk Bank dalam rangka penghimpunan dana terdiri dari deposito dan tabungan sedangkan jenis kredit terdiri dari kredit modal kerja dan kredit konsumtif.

Dilihat dari segi perkembangan dan target pasar sampai dengan Desember 2013 yang menjadi target pasar PD.BPR. khususnya di bidang perkreditan perkembangannya cukup signifikan terlihat dari pertumbuhan outstanding credit (OSC) dua tahun terakhir mengalami pertumbuhan sebesar 25,70 $\%$.Sedangkan target pasar ke depan adalah untuk bidang dana, sasaran utamanya adalah masih sebagian besar pada pedagang - pedagang kecil baik yang di pasar-pasar maupun di dusundusun yang belum di tangani oleh petugas bank yang nantinya kredit juga dapat ditingkatkan untuk semua sektor sesuai dengan potensi wilayah.

\section{Perkembangan Usaha Bank Umum dengan BPR}

Untuk melihat perkembangan usaha Bank Umum dibandingkan dengan BPR selama dua tahun terakhir, maka dapat dilihat dari kondisi laporan keuangan tahunan yang telah dicapai selama ini. Untuk lebih jelasnya dapat dilihat dari tabel di bawah :

Tabel : 1. Share BPR Terhadap Bank Umum Dilihat dari Segi Asset, DPK dan Kredit.

\begin{tabular}{|l|c|c|c|}
\hline $\begin{array}{c}\text { (Dalam Jutaan } \\
\text { Rupiah) }\end{array}$ & Bank Umum & BPR & Share BPR \\
\hline Asset & 21.661 .191 & 985.756 & $4,35 \%$ \\
\hline DPK & 13.886 .075 & 613.412 & $4,23 \%$ \\
- Giro & 2.665 .130 & - & $0,00 \%$ \\
- Tabungan & 7.539 .448 & 351.570 & $4,46 \%$ \\
- Deposito & 3.681 .457 & 261.841 & $6,64 \%$ \\
\hline Kredit & 17.408 .083 & 773.155 & $4,25 \%$ \\
- Lancar & 17.135 .210 & 696.381 & $3,91 \%$ \\
- Non Perform & 272.873 & 76.774 & $21,96 \%$ \\
\hline
\end{tabular}

Sumber : Otoritas Jasa Keuangan Provinsi NTB.

\section{Perkembangan Asset, DPK dan Kredit}

Selanjutnya untuk melihat pertrumbuhan Asset, DPK dan Kredit secara nominal selama priode tahun 2010-2013 dapat disajikan melalui tabel di bawah ini.

Tabel 2. Pertumbuhan Asset, DPK dan Kredit Tahun 2010-2013

\begin{tabular}{|l|c|c|c|c|c|r|r|r|}
\hline \multirow{2}{*}{ Dalam Jutaan } & & & & \multicolumn{3}{|c|}{ Pertumbuhan } \\
\cline { 7 - 10 } & & Dec-10 & Dec-11 & Dec-12 & Sep-13 & Nominal & $\%$ & BU (\%) \\
\hline Asset & $:$ & 656,652 & 815,288 & 975,059 & 985,767 & 10,708 & 1.10 & 11.01 \\
\hline DPK & $:$ & 406,353 & 506,014 & 602,669 & 613,412 & 10,742 & 1.78 & 9.06 \\
\hline - Tabungan & $:$ & 206,269 & 295,173 & 354,739 & 351,570 & $(3,169)$ & -0.89 & 5.20 \\
\hline - Deposito & $:$ & 200,088 & 210,841 & 247,931 & 261,841 & 13,910 & 5.61 & 22.42 \\
\hline Kredit & $:$ & 508,088 & 603,794 & 706,984 & 773,155 & 66,171 & 9.36 & 16.25 \\
\hline
\end{tabular}

Sumber : Otoritas Jasa Keuangan (OJK) Provinsi NTB.

Berdasarkan data pada tabel di atas dapat dijelaskan bahwa sejak priode Tahun 2010 perkembangan jumlah Asset mengalami pertumbuhan cukup significan sampai dengan Tahun 2013. Secara nominal perkembangan Asset meningkat rata-rata sebesar 11,01 persen, DPK pada kurun waktu yang sama meningkat ratarata sebesar 9,06 persen. Jika dilihat secara lebih detail kontribusi DPK 
dominan disumbangkan oleh Deposito masyarakat sebesar 22,42 persen dan selebihnya disumbangkan oleh factor tabungan sebesar 5,20 persen. Keadaan ini mengindikasikan bahwa kecendrungan masyarakat untuk menyimpan dananya di lembaga perbankan lebih cenderung pada warkat deposito dibandingkan dengan tabungan. Demikian pula untuk perkembangan kredit pada kurun waktu Tahun 2010 sampai dengan Tahun 2013 telah mengalami pertumbuhan sebesar 16,25 persen.

Secara grafis perkembangan nilai Asset, DPK dan Kredit selama kurun waktu 2010 sampai dengan Tahun 2013 dapat dilihat pada diagram di bawah.

Selanjutnya untuk melihat jumlah rekening kredit dan DPK pada Bank Umum dan BPR akan disajikan dalam tabel di bawah ini.

Tabel 3. Jumlah Rekening Kredit dan DPK pada Bank Umum dan BPR di Nusa Tenggara Barat Tahun 2012-2013.

\begin{tabular}{|l|r|r|r|r|r|r|r|r|}
\cline { 2 - 9 } & \multicolumn{2}{|c|}{ BANK UMUM } & \multicolumn{2}{c|}{ Pertumbuhan } & \multicolumn{2}{c|}{ BPR } & \multicolumn{2}{c|}{ Pertumbuhan } \\
\cline { 2 - 10 } & 2012 & 2013 & Nominal & $\%$ & 2012 & 2013 & Nominal & $\%$ \\
\hline Kredit & 273.774 & 281.616 & 7.842 & 2,86 & 75.727 & 73.486 & $(2.241)$ & $-2,96$ \\
\hline DPK & 1.390 .977 & 1.521 .584 & 130.607 & 9,39 & 229.779 & 242.420 & 12.641 & 5,50 \\
\hline - Giro & 13.829 & 15.443 & 1.614 & 11,67 & - & - & - & 0,00 \\
\hline - Tabungan & 1.364 .987 & 1.493 .570 & 128.583 & 9,42 & 223.047 & 236.383 & 13.336 & 5,98 \\
\hline - Deposito & 12.161 & 12.571 & 410 & 3,37 & 6.732 & 6.037 & $(695)$ & $-10,32$ \\
\hline
\end{tabular}

Sumber : Otoritas Jasa Keuangan Provinsi NTB.

Berdasarkan data pada tabel di atas dapat ditunjukkan bahwa perkembangan rekening kredit pada Bank Umum dari tahun 2012 sebanyak 273.774 meningkat pada tahun 2013 menjadi 281.616 atau terjadi peningkatan sebesar 2,86 persen. Sedangkan perkembangan rekening kredit pada BPR dari tahun 2012 sebanyak 75.727 meningkat pada tahun 2013 menjadi 73.486 atau terjadi penurunan sebesar -2,96 persen. Ini mengindikasikan bahwa pada Bank Umum rekening kredit mengalami peningkatan, sementara rekening kredit pada BPR justru mengalami penurunan. Kondisi ini memberikan informasi kepada kita bahwa penurunan rekenuing kredit pada BPR lebih dominan disebabkan oleh unsur kehati-hatian dalam penyaluran kredit karena disebabkan oleh meningkatnya NPL pada tahun 2012.Jika dilihat dari segi jumlah kantor yang ada antara Bank Umum dengan BPR di Nusa Tenggara Barat sampai tahun 2014 dapat ditunjukkan seperti data di bawah ini :

Tabel 4. Jenis Kantor Pada Bank Umum dan BPR di Nusa Tenggara Barat

\begin{tabular}{|l|c|c|}
\hline Jenis Kantor & Bank Umum & BPR \\
\hline Kantor Pusat & 1 & 42 \\
\hline KC / KCP & 229 & 34 \\
\hline KK & 46 & 114 \\
\hline Jumlah & 276 & 48 \\
\hline
\end{tabular}

Sumber : Otoritas Jasa Keuangan Provinsi NTB.

\section{Pertumbuhan Lima BPR Terbesar Menurut Asset}

Dilihat dari sisi kuantitas, BPR yang ada di Nusa Tenggara Barat sampai dengan Tahun 2014 telah berjumlah 32 unit dan 
tersebar di seluruh kabupaten/kota. Namun dari jumlah di atas ada 5 (lima) BPR di Nusa Tenggara Barat ini yang memiliki perkembangan jumlah Asset yang cukup mengesankan seperti yang tercantum pada tabel di bawah:

Tabel 5. Pertumbuhan Lima BPR Terbesar Menurut Asset

\begin{tabular}{|l|c|c|}
\hline \multicolumn{1}{|c|}{ Nama BPR } & Asset (dlm Jutaan Rp) & Share \\
\hline PT BPR Prima Nadi & 118.626 & $12,03 \%$ \\
\hline PT BPRS Dinar Asri & 91.957 & $9,33 \%$ \\
\hline PD BPR NTB Sumbawa & 87.096 & $8,84 \%$ \\
\hline PD BPR NTB Lombok Tengah & 85.491 & $8,67 \%$ \\
\hline PT BPR Samawa Kencana & 81.850 & $8,30 \%$ \\
\hline JUMLAH & 465.021 & $47,17 \%$ \\
\hline
\end{tabular}

Sumber : Otoritas Jasa Keuangan Provinsi NTB.

Berdasarkan data pada tabel di atas menunjukkan bahwa Pertumbuhan Lima BPR Terbesar menurut Asset di Nusa Tenggara Barat terdiri dari PT BPR Prima Nadi dengan total Asset sebesar 118.626 milyar selanjutnya diikuti oleh PT. BPR Dinar Ashri dengan total Asset sebesar 91.957 milyar, PD. BPR NTB Sumbawa dengan total Asset sebesar 87.096 milyar, PD BPR Lombok Tengah dengan total Asset sebesar 85.491 milyar dan terakhir PT. BPR Samawa Kencana dengan total Asset sebesar 81.850 milyar. Dilihat dari kelima BPR tersebut ternyata ada 3 (tiga) BPR yang dimiliki oleh pihak swasta dan 2 (dua) BPR yang dimiliki oleh pemerintah daerah (Provinsi dan kabupaten/kota).
Dari data di atas menunjukkan bahwa political will pemerintah daerah masih lebih rendah jika dibandingkan dengan pihak swasta dalam mengembangkan Bank Perkreditan Rakyat (BPR), padahal secara factual daya ungkit BPR dalam meningkatkan pertumbuahn ekonomi daerah cukup significan yang dikarenakan oleh kredit yang diberikan kepada masyarakat lebih dominan pada masyarakat usaha marjinal di seluruh pelosok wilayah Nusa Tenggara Barat.

\section{Pertumbuhan Lima BPR Menurut Dana Pihak Ketiga (DPK)}

Selanjutnya akan disajikan pertumbuhan lima BPR terbesar menurut serapan Dana Pihak Ketiga (DPK) seuai table di bawah.

Tabel 6. Pertumbuhan Lima BPR Terbesar Menurut Dana Pihak Ketiga

\begin{tabular}{|l|c|c|}
\hline \multicolumn{1}{|c|}{ Nama BPR } & DPK (dlm Jutaan Rp) & Share \\
\hline PT BPR Prima Nadi & 101.191 & $16,50 \%$ \\
\hline PT BPRS Dinar Asri & 72.864 & $11,88 \%$ \\
\hline PD BPR NTB Sumbawa & 53.517 & $8,72 \%$ \\
\hline PD BPR NTB Lombok Tengah & 50.347 & $8,21 \%$ \\
\hline PT BPR Samawa Kencana & 47835 & $7,80 \%$ \\
\hline JUMLAH & 325.754 & $53,11 \%$ \\
\hline
\end{tabular}

Sumber : Otoritas Jasa Keuangan Provinsi NTB.

Berdasarkan data tersebut di atas bahwa serapan dana pihak ketiga terbesar dialami oleh PT. BPR Prima Nadi dengan serapan dana sebesar 101.191 milyar atau sekitar 16,50 persen, selanjutnya diikuti oleh PT. BPR Samawa Kencana dengan serapan dana sebesar 72.864 milyar atau sekitar 11,88 persen, PT. BPRS Dinar Ashri dengan serapan dana sebesar 53.517 milyar atau sekitar 8,72 persen, PD.BPR Lombok Tengah dengan serapan dana sebesar 50.347 milyar atau sekitar 8,21 persen dan terakhir PD. BPR NTB Sumbawa dengan serapan dana sebesar 47.835 milyar atau sekitar 7,80 persen. Dilihat dari data tersebut Nampak dominasi BPR swasta masih mendominasi sesuai dengan alsana tersebut di atas juga.

\section{Pertumbuhan Lima BPR Terbesar Menurut Kredit}

Disamping pertumbuhan lima BPR berdasarkan Asset dan DPK, maka 
selanjutnya akan disajikan pertumbuhan BPR dilihat dari sudut pandang

penyaluran kredit.

Tabel 7. Pertumbuhan Lima BPR Terbesar Menurut Kredit

\begin{tabular}{|l|c|c|}
\hline \multicolumn{1}{|c|}{ Nama BPR } & Kredit (dlm Jutaan Rp) & Share \\
\hline PT BPR Prima Nadi & 84.093 & $10,88 \%$ \\
\hline PT BPRS Dinar Asri & 80.363 & $10,39 \%$ \\
\hline PD BPR NTB Sumbawa & 75.267 & $9,73 \%$ \\
\hline PD BPR NTB Lombok Tengah & 59.865 & $7,74 \%$ \\
\hline PT BPR Samawa Kencana & 58.653 & $7,59 \%$ \\
\hline \multicolumn{1}{|c|}{ JUMLAH } & 358.242 & $46,34 \%$ \\
\hline
\end{tabular}

Sumber : Otoritas Jasa Keuangan Provinsi NTB.

Selanjutnya jika dilihat dari segi pertumbuhan kredit ternyata dari lima BPR di atas tampak PT. BPR Prima Nadi mempunyai nilai kredit yang disalurkan kepada masyarakat sebesar 84.093 milyar atau share terhadap nilai kredit sekitar 10,88 persen, selanjutnya diikuti oleh PD.BPR NTB Lombok Tengah sebesar 80.363 milyar atau share terhadap nilai kredit sekitar 10,39 persen, PD. BPR Sumbawa sebesar 75.267 milyar atau share terhadap nilai kredit sekitar 9,73 persen, PD. BPR NTB Lombok Barat sebesar 59.865 milyar atau share terhadap nilai kredit sekitar 7,74 persen dan terakhir PT. BPR Samawa Kencana sebesar 58.653 milyar atau share terhadap nilai kredit sekitar 7,59 persen.Selanjutnya untuk melihat pertumbuhan Nilai Asset, DPK dan Kredit Bank Konvensional jika dibandingkan dengan Bank Syariah, maka akan dapat disajikan pada tabel di bawah ini.

Tabel 8. Pertumbuhan Nilai Asset, DPK dan Kredit Bank Konvensional Vs Bank Syariah

\begin{tabular}{|c|c|c|c|c|}
\hline \multirow[t]{2}{*}{ Dalam jutaan Rp } & \multicolumn{2}{|c|}{ Nominal } & \multicolumn{2}{|l|}{ Share } \\
\hline & Konvensional & Syariah & Konvensional & Syariah \\
\hline Asset & 865.510 & 120.257 & $87,80 \%$ & $12,20 \%$ \\
\hline DPK & 542.753 & 70.659 & $88,48 \%$ & $11,52 \%$ \\
\hline Kredit & 694.366 & 78.789 & $89,81 \%$ & $10,19 \%$ \\
\hline NPL (nominal) & 72.257 & 4.516 & $94,12 \%$ & $5,88 \%$ \\
\hline NPL (\%) & 10,41 & 5,73 & & \\
\hline $\operatorname{LDR}(\%)$ & 127,93 & 111,51 & & \\
\hline ROA (\%) & 3,73 & 7,19 & & \\
\hline
\end{tabular}

Sumber : Otoritas Jasa Keuangan Provinsi NTB.

Berdasarkan data yang tersaji di atas dapat dijelaskan bahwa pertumbuhan nilai Asset Bank Konvensional cukup tinggi jika dibandingkan dengan Bank Syariah di Nusa tenggara Barat. Secara nominal pertumbuahn nilai asset Bank Konvensional dimaksud sebesar 865.510 milyar dengan share sebesar 87,80 persen terhadap total Asset perbankan, selanjutnya diikuti oleh pertumbuhan nilai Asset perbankan Syariah sebesar 120.257 milyar dengan share sebesar 12,20 persen terhadap total Asset perbankan. Sementara jika dilihat dari segi serapan Dana Pihak Ketiga (DPK) Bank Konvensional sebesar 542.753 milyar dengan share sebesar 88,48 persen terhadap total Asset perbankan. Selanjutnya diikuti oleh pertumbuhan nilai Asset perbankan Syariah sebesar 70,659 milyar dengan share sebesar 11,52 persen terhadap total Asset perbankan. Selanjutnya jika dilihat dari segi jumlah penyerapan kredit Bank Konvensional dimaksud sebesar 694.366 milyar dengan share sebesar 89,81 persen terhadap total Asset perbankan. Selanjutnya diikuti oleh pertumbuhan nilai Kredit perbankan Syariah sebesar 78.789 milyar dengan share sebesar 10,19 persen terhadap total Asset perbankan.

Dilain sisi jika dilihat dari aspek NPL nominal Bank Konvensional sebesar72.257 milyar dengan share 
sebesar 94,12 persen terhadap total NPL perbankan konvensional, sedangkan besarnya NPL nominal Bank Syariah sebesar 4.516 milyar dengan share sebesar 94,12 persen 5,88 persen terhadap total NPL perbankan Syariah. Namun jika dilihat secara persentase Nampak dengan jelas bahwa NPL Bank Konvensional sebesar 10,41 persen, sedangkan NPL Bank Syariah sebesar
5,73 persen atau dengan kata lain perbankan Syariah jauh lebih baik dibandingakn dengan perbankan konvensional sesuai dengan ketentuan Peraturan Bank Indonesia (PBI).

Selanjutnya akan disajikan pertumbuhan jenis kredit terhitung sejak tahun 2012 sampai dengan 2013 pada 3 (tiga) sektor ekonomi. Untuk lebih jelasnya dapat dilihat padsa tabel di bawah.

Tabel 9. Pertumbuhan Jenis Kredit Sejak Tahun 2012-2013.

\begin{tabular}{|c|c|c|c|c|c|}
\hline \multirow{2}{*}{ JENIS } & \multirow{2}{*}{ Des'12 } & \multirow{2}{*}{ Sept'13 } & \multicolumn{2}{|c|}{ Pertumbuhan } & \multirow{2}{*}{$\begin{array}{c}\text { Share } \\
\%\end{array}$} \\
\hline & & & Nominal & $\%$ & \\
\hline Modal Kerja & 441.370 & 479.788 & 38.418 & 8,70 & 62,06 \\
\hline Investasi & 44.555 & 54.799 & 10.245 & 22,99 & 7,09 \\
\hline Konsumsi & 221.059 & 238.568 & 17.509 & 7,92 & 30,86 \\
\hline Jumlah & $706.983,95$ & $773.155,22$ & $66.171,28$ & 9,36 & 100,00 \\
\hline
\end{tabular}

Sumber : Otoritas Jasa Keuangan Provinsi NTB.

Berdasarkan data tersebut di atas dapat dijelaskan bahwa terhitung sejak tahun 2012 sampai dengan tahun 2013 pertumbuhan nilai kredit modal kerja masih merupakan dominasi dan prioritas penyaluran kredit di BPR sesuai dengan filisofi pendirian BPR untuk mendongkrak pertumbuhan ekonomi masyarakat di pedesaan melalui usaha kecil dan menengah (UKM). Secara nominal kredit modal kerja per September 2013 sebesar 479.788 milyar atau share sekitar 62,06 persen terhadap total kredit modal kerja. Selanjutnya pertumbuhan kredit konsumsi sebesar 238.568 milyar atau share sekitar 30,86 persen terhadap total kredit modal konsumsi. Sementara penyaluran kredit untuk kredit investasi masih berada pada posisi sebesar 54.799 milyar atau share sekitar 7,09 persen terhadap total kredit investasi. Sedangkan untuk melihat bagaimana pertumbuhan penyaluran kredit berdasarkan seluruhsektor ekonomi akan dapat disajikan pada tabel di bawah

Tabel 10. Pertumbuhan Jenis Kredit dan Berdasarkan Sektor Ekonomi Terhitung Sejak Tahun 2012 - 2013.

\begin{tabular}{|l|r|r|r|r|r|}
\hline \multirow{2}{*}{ JENIS } & \multirow{2}{*}{ Des'12 } & \multirow{2}{*}{ Sept'13 } & \multicolumn{2}{|c|}{ Pertumbuhan } & \multirow{2}{*}{\begin{tabular}{c} 
Share \\
\cline { 5 - 6 }
\end{tabular}} \\
& & & Nominal & \multicolumn{1}{c}{$\%$} & \multicolumn{1}{c}{$\%$} \\
\hline Pertanian dan perikanan & $38.257,45$ & $43.476,96$ & 5.220 & 13,64 & 5,62 \\
\hline Pertambangan dan Penggalian & 319,63 & 623,51 & 304 & 95,07 & 0,08 \\
\hline Industri Pengolahan & $2.317,00$ & $2.370,99$ & 54 & 2,33 & 0,31 \\
\hline Listrik, Gas dan Air & 204,58 & 164,40 & $(40)$ & $(19,64)$ & 0,02 \\
\hline Konstruksi & $15.360,14$ & $13.923,86$ & $(1.436)$ & $(9,35)$ & 1,80 \\
\hline Perdagangan Besar dan Eceran & $379.344,67$ & $408.125,68$ & 28.781 & 7,59 & 52,79 \\
\hline Penyediaan Akomodasi dan Konsumsi & 896,98 & $1.304,89$ & 408 & 45,48 & 0,17 \\
\hline Transportasi, Pergudangan dan Komunikasi & $17.018,43$ & $18.210,77$ & 1.192 & 7,01 & 2,36 \\
\hline Perantara Keuangan & 255,44 & 429,12 & 174 & 67,99 & 0,06 \\
\hline Real Estate & $2.808,14$ & $2.429,77$ & $(378)$ & $(13,47)$ & 0,31 \\
\hline Administrasi Pemerintahan & 269,94 & 252,61 & $(17)$ & $(6,42)$ & 0,03 \\
\hline Jasa-jasa & $21.539,21$ & $30.183,62$ & 8.644 & 40,13 & 3,90 \\
\hline Lain-lain & $228.392,34$ & $251.659,05$ & 23.267 & 10,19 & 32,55 \\
\hline Jumlah & $706.983,95$ & $773.155,22$ & $66.171,28$ & 9,36 & 100,00 \\
\hline
\end{tabular}


Sumber :Otoritas Jasa Keuangan

Berdasarkan data yang ada pada tabel di atas menunjukkan bahwa penyaluran kredit tertinggi disalurkan pada sektor perdagangan besar dan eceran yaitu sebesar 408.125,68 milyar atau sekitar 52,72 persen terhadap total kredit yang ada. Selanjutnya diikuti oleh sektor lainlain sebesar 251.659,05 milyar atau sekitar 32,50 persen terhadap total kredit. Berikutnya diikuti oleh sektor Pertanian dan Perikanan dan sektor Jasa-jasa.

\section{KESIMPULAN DAN SARAN}

\section{Kesimpulan}

1. Dari 32 (tiga puluh dua) Bank perkreditan Rakyat (BPR) yang ada di Provinsi Nusa Tenggara Barat sampai dengan Tahun 2013 ditemukan ada 5 (lima) BPR yang mempunyai Asset terbanyak dari 32 BPR yang ada di Nusa tenggara Barat seperti : PT. BPR Prima Nadi dengan Asset 118.626 milyar, PT. BPRS Dinar Ashri dengan Asset 91.957 milyar, PD.BPR NTB Sumbawa dengan Asset 87.096 milyar, PD.BPR.Lombok Tengah dengan Asset 85.451 milyar dan PT.BPR Samawa Kencana dengan asset 81.850 milyar

2. Dilihat dari segi penyerapan Dana Pihak Ketiga ada 5 (lima) BPR yang mampu menyerap dana pihak ketiga tertinggi dari 32 BPR yang ada di Nusa Tenggara Barat seperti : PT.BPR.Prima Nadi sebesar 101.191 juta, PT.BPR Samawa Kencana sebesar 72.864 juta, PT. BPRS Dinar Ashri sebesar 53.517 juta, PD.BPR Lombok Tengah sebesar 50.347 juta dan PD.BPR.NTB Sumbawa sebesar 47.835 juta.
Sedangkan penyaluran kredit terendah disalurkan pada sektor ekonomi Listrik, Gas dan Air yaitu sebesar 164,40 milyar atau sekitar 0,02 persen. Kondisi ini mengindikasikan bahwa penyaluran kredit kepada masyarakat lebih berorientasi pada sektor ekonomi produktif yang sekaligus dapat berfungsi sebagai daya ungkit pertumbuhan ekonomi di Nusa Tenggara Barat.

3. Dari segi Kredit ada 5 (lima) BPR yang telah menyalurkan kredit terbanyak dari 32 BPR yang ada di Nusa Tenggara Barat seperti : PT.BPR Prima Nadi sebesar 84.093 juta, PD.BPR NTB Lombok Tengah sebesar 80.363 juta, PD.BPR NTB Sumbawa sebesar 75.267 juta, PD BPR NTB Lombok Barat sebesar 59.865 juta dan PT BPR Samawa Kencana sebesar 58.653 juta

\section{Saran}

1. Untuk mempertahankan likuiditas Bank Pedrkreditan Rakyat (BPR) pada moment-moment tertentu sekitar bulan Mei-Juli pemerintah hendaknya dapat menempatkan dananya sebelum digunakan agar likuiditas BPR tidak mengalami penurunan.

2. Pemerintah disamping penempatan dana melalui setoran modal juga dapat menempatkan dananya melalui Deposito berjangka pada bank Perkreditan Rakyat (BPR).

3. Penyaluran kredit oleh Bank Perkreditan Rakyat (BPR) hendaknya lebih diprioritaskan pada kredit yang bersifat produktif baik untuk kepentingan modal usaha maupun untuk kredit sektor pertanian sesuai dengan visi dan misi pendirian 


\section{DAFTAR PUSTAKA}

Anonim, 2006. Peraturan Menteri Dalam Negeri Nomor 22 Tahun 2006Tentang Pengelolaan Bank Perkreditan Rakyat Milik Pemerintah Daerah.

2006. Peraturan Bank Indonesia Nomor: 8/26/PBI/2006 tentang Bank Perkreditan

Rakyat.2009Tentang Penyertaan Modal Pemerintah Provinsi Nusa Tenggara BaratPada Bank Perkreditan Rakyat Nusa Tenggara Barat.

2007. Perda No. 10/2007 tentang Peraturan Daerah Bank Rakyat Provinsi Nusa

Tenggara Barat.

2008. Peraturan Bank Indonesia Nomor: 10/35/PBI/2008 tentang Fasilitas

Pendanaan Jangka Pendek Bagi Bank Perkreditan Rakyat

, 2009. Peraturan Bank Indonesia Nomor: 11/13/pbi/2009 tentang Batas

Maksimum Pemberian Kredit Bank Perkreditan Rakyat.

2009. Peraturan Gubernur Nusa Tenggara Barat Nomor 17 tahun 2009Tentang

Perubahan Atas Peraturan Gubernur Nusa Tenggara Barat Nomor 14 a Tahun

2008 Tentang Anggaran Dasar dan Petunjuk Operasional Perusahaan Daerah

Bank Perkreditan Rakyat di Nusa Tenggara Barat.

, 2010. Peraturan Daerah Provinsi Nusa Tenggara Barat Nomor 6 Tahun 2010

tentang Penyertaan Modal Pemerintah Provinsi Nusa Tenggara Barat pada

Perseroan Terbatas, Perusahaan Daerah dan Perusahaan Swasta

2011. Peraturan Bank Indonesia Nomor : 13/ 26 /PBI/2011tentangPerubahan

Atas Peraturan Bank Indonesia Nomor 8/19/pbi/2006 tentang Kualitas Aktiva

Produktif dan Pembentukan Penyisihan Penghapusan Aktiva Produktif Bank Perkreditan Rakyat.

Husein Umar, 2002. Research Methods in Finance and Banking, Jakarta Business Research Center, jakarta.

Nopirin, Ph.D. Ekonomi Moneter, Edisi ke 1 Buku II, Balai Penerbit Fakultas

Ekonomi Gadjah Mada BPFE UGM, Yogyakarta.

Sri Susilo.Y, Sigit Triandaru,A. Totok Budi Santoso, 2000. Bank dan Lembaga Keuangan lainnya, Penerbit Salemba Empat. Jakarta. 